\title{
THE EFFECTS OF EXOGENOUS PLANT GROWTH REGULATOR ON MORPHOLOGICAL CHARACTERISTICS OF ALFALFA (MEDICAGO X VARIA T. MARTYN)
}

\author{
SOSNOWSKI, J. - JANKOWSKI, K. - MALINOWSKA, E. - KRÓL, J. - REDZIK, P. \\ Institute of Agronomy, Siedlce University of Natural Sciences and Humanities, \\ 08 -110 Siedlce, ul. B. Prusa 14, Poland \\ *Corresponding author \\ e-mail: jacek.sosnowski@uph.edu.pl \\ (Received $17^{\text {th }}$ May 2016; accepted 22 ${ }^{\text {nd }}$ Jul 2016)
}

\begin{abstract}
In 2009 an experiment was set up in order to determine the effects of an exogenous growth regulator on morphological traits of alfalfa (Medicago x varia T. Martyn). The regulator was based on auxin and cytokinin. The tested features included: shoot mass, the number of shoots per plant, root collar diameter, and leaf area. The experiment lasted three years, with three cuts of alfalfa harvested each year. The growth regulator increased biomass weight, root collar diameter, and the leaf area but it did not affect the number of shoots per plant. Studies also showed a significant relationship between the diameter of the root collar and shoot weight as well as the number of shoots. Plants with larger root collar produced more shoots with a higher weight.
\end{abstract}

Keywords: plant, growth regulator, biomass, cultivation, Ecklonia maxima

\section{Introduction}

Hybrid alfalfa is a source of many chemical products with multiple pharmacological activities (Barnes et al., 2002; Zgórka and Głowniak, 2008). A variety of chemical compounds present in alfalfa determines the multidirectional pharmacological action of extracts derived from it (Massiot et al., 1991; Stochmal et al., 2001; Huhman and Sumner, 2002). Additionally, because it contains important vitamins, Fe and $\mathrm{K}$, it is used to treat anaemia and vitamin deficiency (Barnes et al., 2002). It purifies the blood, removes toxins, balances blood sugar level, and improves nutrient absorption. Alfalfa saponins lower cholesterol concentration in the blood and have antiviral, antifungal, anti-inflammatory, and antioxidant properties (Francis et al., 2002). The European Union Commission decision 2009/826/EC of 13 October 2009 authorised the placing a leaf extract from alfalfa as food supplement on the market. In accordance with this decision alfalfa protein concentrate is safe for human consumption if it contains such chemical compounds as L-canavanine, and if its daily dose does not exceed $10 \mathrm{~g}$ (Barnes et al., 2002). In view of the above, research on treating alfalfa with synthetic growth regulators makes it possible to obtain new insight into its mechanism of action. The placing of an extract from the leaves as a novel food ingredient on the market by the Commission of the European Communities can help to enhance the value of alfalfa among agricultural crops.

Alfalfa can be successfully grown throughout the whole of Poland and in most European countries, but only when the basic requirements of habitat and agronomy are fulfilled (Ćwintal, 2000; Zając, 2007; Ćwinatal and Wilczek, 2008). Environmentally friendly nature of alfalfa cultivation is worth emphasising. It is important for sustainable agricultural production due to the symbiosis with bacteria of Rhizobium meliloti, converting atmospheric nitrogen to make it available to the plant. 
It also increases the amount of organic matter in the soil and improves its physical properties (Ćwinatal and Wilczek, 2008). Alfalfa yield potential is high, which is indicated by the results of many experiments (Broniarz, 2009). Correct methods of cultivation ensure a high production of aboveground biomass, proper plant density, and canopy structure (Wilczek, et al., 1999).

Recently there has been a growing interest in new substances the use of which will improve the productivity and health of crops, while reducing the use of fertilizers and plant protection products. An example of this may be an extract from seaweeds. Literature data show a positive impact of this preparation on plants (Verkeley, 1992); its effects have been characterized by a yield increase, resulting primarily from an increase of resistance to unfavourable environmental factors (drought, frost), greater resistance to pathogens and pests, and more intense uptaking of nutrients from the soil (Bai et al., 2007). Bio stimulating effects of such extracts are related to the presence of plant hormones, primarily cytokinins, responsible for cell division regulation, cell volume increase, and the differentiation of the chloroplast. In addition, they are involved in the regulation of plant aging and induce the differentiation of shoots. Different species of algae are different in cytokinin content and their proportion in relation to other plant hormones and, therefore, the effect of these extracts is heterogeneous (Matysiak, 2005; Matysiak and Adamczewski, 2005). Furthermore, algae are rich in micro and macronutrients required for plant growth. Studies have shown that the effect of use of the extract is dependent on the concentration, method of application, and the plant species (Sultana, et al., 2005).

The aim of this study was to determine the effect of plant growth regulator Kelpak (extract of Ecklonia maxima) on morphological traits of hybrid alfalfa grown in pure stand. The three-year study tested the variability of root collar diameter, mass of shoots, the number of shoots per plant, and leaf area under the influence of Kelpak on successive growths of alfalfa.

\section{Materials and methods}

\section{Design of the experiment}

In 2009, a field experiment with alfalfa (Medicago x varia T. Martyn - Tula variety) was set up on the experimental object of the Department of Grasslands and Landscape Architecture Development in Siedlce. According to the Polish classification system the soil on which the experimental was carried out was of the order of anthrosole and hortisole type, formed from light loamy sand.

An analysis carried out at the Regional Chemical Station in Wesoła found that the soil was of neutral $\mathrm{pH}(\mathrm{pH}$ in $1 \mathrm{n} \mathrm{KCl}=7.2)$, with a high content of humus $(3.78 \%)$, available phosphorus $\left(\mathrm{P}_{2} \mathrm{O}_{5}-900 \mathrm{mg} \cdot \mathrm{kg}^{-1}\right)$ and magnesium $\left(\mathrm{Mg}-84 \mathrm{mg} \cdot \mathrm{kg}^{-1}\right)$ and a moderate content of total nitrogen $\left(\mathrm{N}-1.8 \mathrm{~g} \cdot \mathrm{kg}^{-1}\right)$ and available potassium $\left(\mathrm{K}_{2} 0-190\right.$ $\left.\mathrm{mg} \cdot \mathrm{kg}^{-1}\right)$. A plot area in the experiment was $6 \mathrm{~m}^{2}$.

Before sowing and in the second and third year phosphorus fertilization was applied in the amount of $45 \mathrm{~kg} \mathrm{P} \cdot \mathrm{ha}^{-1}$ and potassium at $100 \mathrm{~kg} \mathrm{~K} \cdot \mathrm{ha}^{-1}$. Alfalfa seeds were sowed in April 2009 at $12 \mathrm{~kg} \cdot \mathrm{ha}^{-1}$ (600 units of $100 \%$ germination per square meter), at a depth of about $1 \mathrm{~cm}$. Growth regulator Kelpak SL, which consists of natural plant hormones such as auxin $\left(11 \mathrm{mg} \cdot \mathrm{l}^{-1}\right)$ and cytokinin $\left(0.03 \mathrm{mg} \cdot \mathrm{l}^{-1}\right)$, was applied during the shooting stage. It is an extract from brown algae Ecklonia maxima. The preparation was applied during each growth period of alfalfa in the form of a spray. The experimental units were 
as follows: A1- control (without the regulator), A2 - application at a dose of $21 \cdot \mathrm{ha}^{-1}$ of the regulator diluted in 350 litters of water. Each experimental combination was replicated three times.

\section{Analysis of selected morphological features}

Throughout the experiment alfalfa was harvested three times a year (B1, B2, B3) in the early stage of flowering. However, from each plot and each growth (with three growths a year) of alfalfa, plants in the early flowering stage were sampled randomly to determine: shoot mass (g DM), the number of shoots per plant, root collar diameter $(\mathrm{mm})$ and leaf area $\left(\mathrm{cm}^{2}\right)$ expressed as the product of leaf lamina length and width (Kluza-Wieloch, 2004).

\section{Data analysis}

The results were analyzed statistically using analysis of variance (ANOVA) with a significance level of $0.05\left(\mathrm{LSD}_{0.05}\right)$ and Tukey's test. Furthermore, Pearson correlation coefficient ( $\mathrm{r}$ ) was calculated in order to determine the relationship between the number of shoots per plant and root collar diameter but also between shoot dry matter and root collar diameter. The coefficient of determination $\left(\mathrm{R}^{2}\right)$ was also calculated as a measure of association between the variables.

\section{Meteorological conditions}

Meteorological data during the research years were obtained from the Hydrological and Meteorological Stations in Siedlce. The location of the study area was $52.169^{\circ} \mathrm{N}$, $22.280^{\circ}$ E. However, in order to determine temporal variability of meteorological elements and their influence on plant growth, Sielianinov's hydrothermal coefficient was calculated (Bac et al., 1993).

The data presented in Table 1 show that the most favourable distribution and the amount of rainfall, with optimum air temperature within the growing season, was in 2009 and 2011. In those years there were no months with drought or strong drought.

Table 1. Value of Sielianinov's hydrothermal coefficient ( $k$ ) throughout the growing seasons

\begin{tabular}{cccccccc}
\hline \multirow{2}{*}{ Year } & \multicolumn{7}{c}{ Month } \\
\cline { 2 - 7 } & Apr. & May & June & July & Aug. & Sept. & Oct. \\
\hline 2009 & 1.03 & 2.24 & 1.03 & 1.26 & 1.36 & 1.01 & 1.73 \\
2010 & 0.40 & 2.21 & 1.19 & 1.18 & 1.79 & 2.81 & 0.53 \\
2011 & 1.10 & 0.89 & 0.72 & 2.19 & 0.84 & 0.78 & 0.94 \\
\hline K < 0.5 - serve drought; $0.51-0.69$ - drought; $0.70-0.99$ & - moderate drought; K > 1 - no drought \\
\hline \multicolumn{7}{c}{}
\end{tabular}

\section{Results and discussion}

Shoot dry matter is one of the main indicators of the yield potential of alfalfa. In the present experiment the cut, research year, and the regulator had a significant impact on the mass of shoots (Table 2). Shoots collected from the first growth had the largest mass (0.96 g DM). In the third growth their average weight decreased by over $14 \%(0.82 \mathrm{~g}$ DM) compared to the first growth, and in the second by $25 \%$ (0.72 g DM). Application of Kelpak, regardless of the cut and the study year, resulted in an increase of shoot 
weight, on average from $0.79 \mathrm{~g} \mathrm{DM}$ (A1) to $0.87 \mathrm{~g} \mathrm{DM}$ (A2), an increase of over $10 \%$. The analysis of research years showed that the shoots with the highest weight (an average of $0.92 \mathrm{~g} \mathrm{DM}$ ) were in the third year of alfalfa cultivation. This was due to weather conditions because during plant vegetation in 2011 , at the stage of formulating and extending the alfalfa shoots, there was not a month with a strong drought, which enhanced the acting of the regulator and contributed to plant growth and development (Table 2).

Table 2. Effect of the growth regulator on shoot weight of hybrid alfalfa [g DM]

\begin{tabular}{|c|c|c|c|c|c|}
\hline \multirow{2}{*}{$\begin{array}{l}\text { Objects } \\
\text { (A) }\end{array}$} & \multirow{2}{*}{$\begin{array}{l}\text { Cut } \\
\text { (B) }\end{array}$} & \multicolumn{3}{|c|}{$\begin{array}{c}\text { Study year } \\
\text { (C) }\end{array}$} & \multirow{2}{*}{ Mean } \\
\hline & & 2009 & 2010 & 2011 & \\
\hline \multirow{3}{*}{$\begin{array}{c}\text { A1 } \\
\text { (control) }\end{array}$} & B1 & 0.86 & 0.85 & 1.02 & 0.91 \\
\hline & B2 & 0.78 & 0.58 & 0.71 & 0.69 \\
\hline & B3 & 0.80 & 0.76 & 0.78 & 0.78 \\
\hline \multicolumn{2}{|c|}{ A1 } & 0.81 & 0.73 & 084 & 0.79 \\
\hline \multirow{3}{*}{$\begin{array}{c}\text { A2 } \\
\text { (regulator) }\end{array}$} & B1 & 0.92 & 0.91 & 1.20 & 1.01 \\
\hline & B2 & 0.84 & 0.56 & 0.87 & 0.76 \\
\hline & B3 & 0.76 & 0.92 & 0.90 & 0.86 \\
\hline \multicolumn{2}{|c|}{ A2 } & 0.84 & 0.79 & 0.99 & 0.87 \\
\hline \multirow{3}{*}{ B } & B1 & 0.89 & 0.88 & 1.11 & 0.96 \\
\hline & B2 & 0.80 & 0.57 & 0.79 & 0.72 \\
\hline & B3 & 0.78 & 0.84 & 084 & 0.82 \\
\hline \multicolumn{2}{|c|}{ Mean } & 0.83 & 0.76 & 0.92 & \\
\hline \multicolumn{6}{|c|}{$\mathrm{LSD}_{0.05}$ for: $\mathrm{A}-0.07 ; \mathrm{B}-0.09 ; \mathrm{C}-0.06 ; \mathrm{AxB}-.07 ; \mathrm{AxC}-\mathrm{NS} ; \mathrm{BxC}-0.09 ; \mathrm{AxBxC}-0.09$} \\
\hline
\end{tabular}

Another characteristic is the number of shoots per plant. It should be noted that this feature did not significantly vary in result of Kelpak application (Table 3). The growth stage also did not significantly affect the number of shoots. The only factor differentiating this value was the year. The smallest number of shoots per plant (5.5) was in 2009, the first year of the experiment. In the following years its value significantly increased, and in the 2011 it stood at 6.1. This is the effect of plant aging on the increase of root collar diameter, which, as statistical analysis showed, significantly positively affected the number of shoots per plant (Table 5). Analysis of the meteorological conditions throughout the experiment does not indicate explicitly the dependence of the above features on the weather conditions during the growing season.

The study showed that the use of the growth regulator resulted in a significant increase in alfalfa root collar diameter (Table 4). It increased on the plots with Kelpak (A2), regardless of the growth period and experimental year, standing, on average, at $8.9 \mathrm{~mm}$. On the control plot (A1) its value was $7.3 \mathrm{~mm}$. In addition, as said above, plant aging increased their collar diameter, and it was the largest in the third year. The growth period did not significantly affect this feature. Root collar diameter of plants grown on the plots with Kelpak (A2), regardless of the cut and the research year, amounted to an average of $8.9 \mathrm{~mm}$. On the control plots (A1) its value was $7.3 \mathrm{~mm}$. It again proves that the growth regulator contributed to the plant growth and development (Table 2). 
Table 3. Effect of the growth regulator on the number of shoots of hybrid alfalfa

\begin{tabular}{|c|c|c|c|c|c|}
\hline \multirow{2}{*}{$\begin{array}{l}\text { Objects } \\
\text { (A) }\end{array}$} & \multirow{2}{*}{$\begin{array}{l}\text { Cut } \\
\text { (B) }\end{array}$} & \multicolumn{3}{|c|}{$\begin{array}{c}\text { Study year } \\
\text { (C) }\end{array}$} & \multirow[t]{2}{*}{ Mean } \\
\hline & & 2009 & 2010 & 2011 & \\
\hline \multirow{3}{*}{$\begin{array}{c}\text { A1 } \\
\text { (control) }\end{array}$} & B1 & 5.1 & 5.8 & 6.6 & 5.8 \\
\hline & B2 & 5.5 & 6.0 & 6.7 & 6.1 \\
\hline & B3 & 5.7 & 5.6 & 5.6 & 6.1 \\
\hline \multicolumn{2}{|l|}{ A1 } & 5.5 & 5.8 & 6.3 & 5.9 \\
\hline \multirow{3}{*}{$\begin{array}{c}\mathrm{A} 2 \\
\text { (regulator) }\end{array}$} & B1 & 4.8 & 6.0 & 5.9 & 5.6 \\
\hline & B2 & 5.1 & 5.8 & 6.5 & 5.8 \\
\hline & B3 & 5.7 & 5.8 & 5.4 & 5.6 \\
\hline \multicolumn{2}{|l|}{ A2 } & 5.3 & 5.9 & 5.9 & 5.7 \\
\hline \multirow{3}{*}{ B } & B1 & 5.1 & 6.0 & 6.3 & 5.8 \\
\hline & B2 & 5.3 & 6.0 & 6.6 & 5.8 \\
\hline & B3 & 5.7 & 5.8 & 5.5 & 5.7 \\
\hline \multicolumn{2}{|l|}{ Mean } & 5.5 & 5.9 & 6,1 & \\
\hline \multicolumn{6}{|c|}{$\mathrm{LSD}_{0.05}$ for: $\mathrm{A}-\mathrm{NS} ; \mathrm{B}-\mathrm{NS} ; \mathrm{C}-0.18 ; \mathrm{AxB}-0.18 ; \mathrm{AxC}-\mathrm{NS} ; \mathrm{BxC}-0.21 ; \mathrm{AxBxC}-0.20$} \\
\hline
\end{tabular}

Table 4. Effect of the growth regulator on root collar diameter [mm]

\begin{tabular}{|c|c|c|c|c|c|}
\hline \multirow{2}{*}{$\begin{array}{l}\text { Objects } \\
\text { (A) }\end{array}$} & \multirow{2}{*}{$\begin{array}{l}\text { Cut } \\
\text { (B) }\end{array}$} & \multicolumn{3}{|c|}{$\begin{array}{l}\text { Study year } \\
\text { (C) }\end{array}$} & \multirow[t]{2}{*}{ Mean } \\
\hline & & 2009 & 2010 & 2011 & \\
\hline \multirow{3}{*}{$\begin{array}{c}\text { A1 } \\
\text { (control) }\end{array}$} & B1 & 5.2 & 5.9 & 9.1 & 6.7 \\
\hline & B2 & 5.3 & 7.8 & 9.3 & 7.5 \\
\hline & B3 & 5.7 & 7.0 & 104 & 7.7 \\
\hline \multicolumn{2}{|c|}{ A1 } & 5.4 & 6.9 & 9.6 & 7.3 \\
\hline \multirow{3}{*}{$\begin{array}{c}\mathrm{A} 2 \\
\text { (regulator) }\end{array}$} & B1 & 7.2 & 8.7 & 11.6 & 9.2 \\
\hline & B2 & 7.1 & 8.6 & 10.4 & 9.1 \\
\hline & B3 & 7.6 & 8.5 & 10.4 & 8.8 \\
\hline \multicolumn{2}{|c|}{ A2 } & 7.3 & 8.6 & 10.8 & 8.9 \\
\hline \multirow{3}{*}{ B } & B1 & 6.2 & 7.3 & 10.4 & 8.0 \\
\hline & B2 & 6.2 & 8.2 & 9.9 & 8.1 \\
\hline & B3 & 6.7 & 7.8 & 10.4 & 8.3 \\
\hline \multicolumn{2}{|c|}{ Mean } & 6.4 & 7.8 & 10.2 & \\
\hline
\end{tabular}

NS- not significant

Table 5. Correlation of morphological characteristics of alfalfa

\begin{tabular}{lcc}
\hline Morphological characteristics & $\mathrm{r}\left(\mathrm{R}^{2}\right)$ & The regression equation \\
\cline { 2 - 3 } & $\begin{array}{c}7.66(58.7 \%)^{*} \\
\mathrm{y}_{1}-\text { Alfalfa shoot weight depending on the } \\
\text { diameter }\end{array}$ & $\mathrm{y}=0.1848+0.0799 \cdot \mathrm{x}$ \\
$\mathrm{y}_{2}$ - Number of shoots per alfalfa plant & $7.87(61.9 \%) *$ & $\mathrm{y}=3.9862+0.1691 \cdot \mathrm{x}$ \\
\hline$*$ - significant for $\mathrm{p}=0.05, \mathrm{~N}=54$ & \\
\hline $\mathrm{r}$ - correlation coefficient, $\mathrm{R}^{2}$ - coefficient of determination
\end{tabular}


In addition, the analysis of the linear dependence between the number of shoots per plant and the root collar diameter as well as between the shoot mass and the diameter of the root collar showed a significant positive correlation between these characteristics (Table 5). The number of shoots per plant of alfalfa in more than $61 \%\left(\mathrm{R}^{2}=61.9 \%\right)$ was dependent on the diameter of the root collar. A similar relationship with $\mathrm{R}^{2}=58.7 \%$ was also in relation to the weight of the shoots.

Treating alfalfa plants with Kelpak contributed to the significant increase in leaf blade area (Table 6). The average area of the blade, regardless of the cut and the study year for the plants grown in plots without the regulator was $13.8 \mathrm{~cm}^{2}$, and the blades of the plants treated with it were $10 \%$ larger $\left(15.3 \mathrm{~cm}^{2}\right)$ than in the control objects. Additionally, weather conditions had a significant effect on the leaf blade area. In the years with no severe drought during the growing season, such as 2009 and 2011 (Table $1)$, the leaf blade area of alfalfa was, on average, more than $8 \%$ larger than the blade area during the drought year.

Table 6. Effect of the growth regulator on leaf area of hybrid alfalfa $\left[\mathrm{cm}^{2}\right]$

\begin{tabular}{|c|c|c|c|c|c|}
\hline \multirow{2}{*}{$\begin{array}{c}\text { Objects } \\
\text { (A) }\end{array}$} & \multirow{2}{*}{$\begin{array}{l}\text { Cut } \\
\text { (B) }\end{array}$} & \multicolumn{3}{|c|}{$\begin{array}{l}\text { Study year } \\
\text { (C) }\end{array}$} & \multirow[t]{2}{*}{ Mean } \\
\hline & & 2009 & 2010 & 2011 & \\
\hline \multirow{3}{*}{$\begin{array}{c}\text { A1 } \\
\text { (control) }\end{array}$} & B1 & 12.4 & 12.1 & 12.7 & 12.4 \\
\hline & B2 & 15.8 & 13.2 & 14.1 & 14.4 \\
\hline & B3 & 13.8 & 13.7 & 16.6 & 14.7 \\
\hline \multicolumn{2}{|c|}{ A1 } & 14.0 & 13.0 & 14.5 & 13.8 \\
\hline \multirow{3}{*}{$\underset{\text { (regulator) }}{\mathrm{A2}}$} & B1 & 16.4 & 13.5 & 14.5 & 14.8 \\
\hline & B2 & 16.2 & 13.2 & 15.7 & 15.0 \\
\hline & B3 & 14.8 & 16.7 & 16.8 & 16.1 \\
\hline \multicolumn{2}{|c|}{ A2 } & 15.8 & 14.5 & 15.7 & 15.3 \\
\hline \multirow{3}{*}{ B } & B1 & 14.4 & 12.8 & 13.6 & 13.6 \\
\hline & B2 & 16.0 & 13.2 & 14.9 & 14.7 \\
\hline & B3 & 14.3 & 15.2 & 16.7 & 15.4 \\
\hline \multicolumn{2}{|c|}{ Mean } & 14.9 & 13.8 & 15.1 & \\
\hline \multicolumn{6}{|c|}{$\mathrm{LSD}_{0.05}$ for: $\mathrm{A}-1.4 ; \mathrm{B}-\mathrm{NS} ; \mathrm{C}-1.2 ; \mathrm{AxB}-1.9, \mathrm{AxC}-1.2 ; \mathrm{BxC}-1.3 ; \mathrm{AxBxC}-2.1$} \\
\hline
\end{tabular}

NS- not significant

Activity of exogenous growth regulators based on phytohormones depends on their concentration, method of application but also on the species and variety of the crop (Sultana et. al., 2005). Literature data show that Kelpak does not harm crops (Verkeley, 1992; Zodape, 2001; Temple and Bomke, 1989; Russell, 2002) but it stimulates some of their organs to increase their size (Matysiak, 2005; Matysiak and Adamczewski, 2005; Pietryga and Matysiak, 2003). This was confirmed by the present study of hybrid alfalfa. The growth regulator caused an increase in weight and leaf blade area of plants. It also contributed to the increase of the root collar diameter. But Bai et al. (2007), as a result of the foliar application of algae extracts, found that, compared to the control, shoots of the plants treated were about 35\% longer, while roots were $22 \%$ longer. Similar results are presented by Thevanathan, et al. (2005). Pietryga and Matysiak (2003) and Matysiak (2005) confirm a positive effect of Kelpak on the yield of plants. However, Matysiak and Adamczewski (2005) point out that the plants which responded to the greatest extent to the use of Kelpak were cereals; Klepak application resulted in an increased yield of more than $21 \%$ compared to the control. The same authors also 
indicate a difference in the response of individual cereals to Kelpak. They found that spring cereals reacted more strongly than winter cereals. It should be noted, however, that there are some publications describing experiments in which there was no significant effect of extracts from algae on plants (De Villiers et al., 1983). Yet in the majority of cases the beneficial effects of Kelpak on crops has been confirmed, often indicating than the time of application is more effective than the dose (Matysiak et al., 2010). In addition, some varieties of the same species respond to exogenous growth regulators stronger than others (Matysiak and Adamczewski, 2006).

\section{Conclusions}

The use of the growth regulator on hybrid alfalfa led to a significant increase in shoot mass, root collar diameter, and leaf area. It had no effect on the number of shoots per plant. However, there was dependence between the root collar diameter and shoot mass as well as the number of shoots per plant. The harvest time of alfalfa only influenced the plant mass. Other morphological features did not undergo significant differentiation under the influence of Kelpak. The weather conditions during the growing season of alfalfa most intensely affected shoot mass and leaf area. A strong spring drought limited the value of these characteristics.

Acknowledgements. The research was carried out under the project of the Ministry of Science and Higher Education for the development of young scientists. Topic title: Effect of biological preparations on soil fertility and productivity of plants alternating grassland; project number 20/MN/11.

\section{REFERENCES}

[1] Bac, A., Koźmiński, C., Rojek, M. (1993): Agrometeorologia. - PWN, Warszawa, pp.32-33.

[2] Bai, N. R., Banu, N.R.L., Prakash, J.W., Goldi, S., J. (2007): Effects of Asparaguses taxiformis extract on the growth and yield of Phaseolus aureus. - Journal of Basic and Applied Biology 1(1): 6-11.

[3] Barnes, J., Anderson, L.A., Phillipson, J.D. (2002): Medicines, $2^{\text {nd }}$ edition.Pharmaceutical Press, London, p. 38.

[4] Broniarz, J. (2009): The results of experiments with different varieties of small seeded Fabaceae. COBORU 1210: 11- 39

[5] Ćwintal, M. (2000): Effect of selected tillage and fertilization methods on self-regulation of plant density, yield structure and quality of Medicago x varia Martyn in 3- and 4-cut systems. Postdoctoral dissertation. Wyd. AR w Lublinie

[6] Ćwintal, M., Wilczek, M. (2008): Methods of growing alfalfa. - In: Regional and Local Studies. South-Eastern Poland. Alfalfa in human and animal nutrition. Monographic edition. Progress, Dzierdziówka - Lublin, pp. 7-19.

[7] De Villiers, J., Kotze, WAG, Joubert, M. (1983): Effect of seaweed foliar spray on fruit quality and mineral nutrition. - The Decidous Fruit Grower 33: 97-101.

[8] EC 2009/826/: Commission Decision of 13 October 2009 authorising the placing on the market of a leaf extract from Lucerne (Medicago sativa) as novel food or novel food ingredient under Regulation (EC) No 258/97 of the European Parliament and of the Council [notified under document C(2009) 7641].

[9] Francis, G., Kerem, Z., Makkar, H.P.S., Becker, K. (2002): The biological action of saponins in animal system: as review. - Br. J. Nutr. 88: 587- 605. 
[10] Huhman, D.V., Sumner, L.,W. (2002): Metabolic profiling of saponins in Medicago sativa and Medicago trunculata using HPLC coupled to an electrospray ion-trap mass spectrometer. - Phytochemistry 59: 347-360.

[11] Kluza-Wieloch, M., Muśnicka, C. (2004): Variability of some morphological and utilitarian characters of shoots and inflorescences of different cultivar types of oleaginous form of sunflower (Helianthus annuus L.) Rośliny Oleiste - Oilseed Crops 25: 423-438.

[12] Massiot, G., Lavaud, C., Besson, V., Le, Men-Olivier, L., Van Binstt, G. (1991): Saponins from aerial parts of alfalfa (Medicago sativa). - J. Agric. Food Chem. 39: 78-82.

[13] Matysiak, K. (2005): Kelpak - a natural regulator of plant growth and development. - In: Zbytek, Z. (ed) Selected environmental problems in modern agriculture. Monography 2., Industrial Institute of Agricultural Engineering 375: 188-193.

[14] Matysiak, K., Adamczewski, K. (2005): Effect of bioregulator Kelpak application in spring wheat on the occurrence of phytophagous insects. - Prog. Plant Protection/Post.Ochr. Roślin 45: 898-902.

[15] Matysiak, K., Adamczewski, K. (2006): Influence of biorerulator Kelpak on yield of cereals and other crops. - Progress in Plant Protection 46(2): 102-108.

[16] Matysiak, K., Kaczmarek, S., Kierzek, R., Kardasz, P. (2010): Effect of seaweeds extracts and humic and fulvic acids on germination and early growth of winter oilseed rape (Brassica napus L.). - Journal of Research and Applications in Agricultural Engineering 55(4): 28-32.

[17] Pietryga, J., Matysiak, K. (2003): Biological effects of Kelpak growth regulator on winter rape. - Prog. Plant Protection/Post.Ochr. Roślin 43: 863-865.

[18] Russell, C. L. (2002): Kelp Based growth stimulants - science or snake oil? - Internal Technical Bulletin of Corbett Pty Ltd.

[19] Stochmal, A., Simonet, A.,M, Macias, F.,A, Oliviera, M.,A, Abreu, J.,M, Nash, R., Oleszek, W. (2001): Acylated apigenin glycosides from alfalfa (Medicago sativa L.) var. Artal. - Phytochemistry 57: 1223-1226.

[20] Sultana, V., Ehteshamul-Haque, S., Ara, J., Athar, M. (2005): Comparative efficacy of brown, green and red seaweeds in the control of root infecting fungi and okra. - Int. J. Environ. Sci. Tech. 2(2): 129-132.

[21] Temple, W., D, Bomke, A., A. (1989): Effects of kelp (Macrocystis integrifolia and Ecklonia maxima) foliar applications on bean crop growth. - Plant Soil 117: 85-92.

[22] Thevanathan, R., Anjanadutta, Dinamani, D.,S, Bhavani, L.,G. (2005): Studies on the impact of application of marine algal manure and liquid fertiliser on the linear growth of the seedlings of some pulses. - Seaweed research utilization 27 (1/2): 125-133.

[23] Verkleij, F. N. (1992): Seaweed extracts in agriculture and horticulture: a review. - Biol. Agric. Hortic. 8: 309-324.

[24] Wilczek, M., Ćwintal, M., Michałowski, Cz. (1999): The yield of different cultivars of alfalfa in 3- and 4-cut systems. - Zesz. Nauk. AR in Krakow 347: 363-368.

[25] Zając, T. (2007): Comparison of selected morphological traits and lucerne species productivity depending on the choice of cover plants. - Advences of Agricultural Sciences Problem Issues 516: 291-301.

[26] Zgórka, G., Głowniak, K. (2008): In vitro and in vivo evaluation of biological activity of alfalfa (Medicago sativa L.) compounds. - In: Grela, E. R. (ed.) Alfalfa in human and animal nutrition. Association for regional and local development „PROGRESS”, Dzierdziówka, pp. 39-47.

[27] Zodape, S. T. (2001): Seaweeds as a biofertilizer. - J. Sci. Industrial Res. 60(5):378-382. 